\title{
Pozzolanic Properties of White Cowpea Husk Ash
}

\author{
Wilson U N 1*, Gambo Z1, Mohammed I S ${ }^{1}$, Eze O C1, Odeyemi S $\mathrm{O}^{2}$
}

1,* Department of Civil Engineering, Nigerian Defence Academy Kaduna, Nigeria.

2 Department of Civil and Environmental Engineering, Kwara State University, Malete, Nigeria.

* Corresponding Author: unwilson@nda.edu.ng

Received: 07-06-2021

Accepted: 07-08-2021

\begin{abstract}
This research attempts to empirically investigate the pozzolanic properties of White Cowpea Husk Ash (WCHA), an agricultural biomass waste, at different percentages of its use as partial replacement of cement in concrete. WCHA was obtained after the calcination of white cowpea husk for 3 hours at $550^{\circ} \mathrm{C}$. X-ray Florescence (XRF) analysis performed revealed that the sample of WCHA is a Class $\mathrm{C}$ pozzolana, which contains $65.4 \%$ of the combination of $\mathrm{SiO}_{2}, \mathrm{Al}_{2} \mathrm{O}_{3}$, and $\mathrm{Fe}_{2} \mathrm{O}_{3}$. The WCHA shows increase in consistency with increase in the WCHA content. This was attributed to the high Loss of Ignition (LOI) of WCHA compared to that of the cement. In addition, the results indicated that the initial and final setting time of WCHA - Cement blended concrete increase with increase in the WCHA content. The delay in setting times of WCPA-Cement paste could be attributable to the slower pozzolanic reaction. The density of the concrete decreased as the WCHA content increases. Generally the compressive strength of the WCHA concrete increased with increase in curing age and decreases as the WCHA content increased from a strength of 28.6 to $20.0 \mathrm{~N} / \mathrm{mm}^{2}$ giving a percentage reduction of $30.1 \%$. The strength reduction is also attributed to the modification of the bonding properties of the binders' hydrates. However, the 28 days compressive strength of concrete with up to $10 \%$ WCHA content $\left(26.4 \mathrm{~N} / \mathrm{mm}^{2}\right)$ satisfied the design characteristic strength of $25 \mathrm{~N} / \mathrm{mm}^{2}$. Beyond this limit, the compressive strength of the concrete fell below the design strength. Hence, $10 \%$ WCHA could be regarded as the optimum dose for grade 25 concrete.
\end{abstract}

Keywords: Concrete, Compressive Strength, White Cowpea Husk Ash (WCHA), X-ray Florescence.

\section{Introduction}

Concrete is reported to be one of the most consumed construction material by man with a worldwide consumption estimated in 2006 of between 21 and 31 billion tonnes (European Concrete, 2009; Odeyemi et al., 2020). Concrete is made from coarse aggregates (gravel or crushed stone), fine aggregates (sand), water, cement and admixtures (European Concrete, 2009).

Cement on the other hand is the most important ingredient in concrete, whose production contributes significantly to the global amount of carbon dioxide $\left(\mathrm{CO}_{2}\right)$ emissions in our environment which is known to be highly inimical and hazardous to human health, making up approximately 2.4 percent of global $\mathrm{CO}_{2}$ emissions from industrial and energy sources (Marland et al., 1989). However, gas emission during cement production can be reduced by the utilization of mineral additives in concrete (Malhotra and Mehta, 2002 and Awang et al., 2016). There have been extensive studies done on the use of the more common mineral additives in concrete such as; Rice Husk Ash (RHA) (Habeeb et al, 2009; Ogork et al, 2010; Atan and Awang, 2011; Aboshio et al, 2018), fine limestone powder (Felekoglu, 2007; Ye et al, 2007; Esping, 2008), pulverizedfuel ash (Sukumar et al., 2008; Liu, 2010; Siddique, 2011), silica fume (Yazici, 2008; Gesoglu et al., 2009; Turkel, 2009). However, lesser interests are shown on other types of mineral additives due to various factors such as: the availability of certain mineral additives, transportation 
problems and heterogeneity of the additives chemical components (Atan and Awang, 2011). A total of 3.3 million tonnes of cowpea dry grain were produced worldwide in 2000 as estimated by Food Agriculture Organization (FAO) (IITA Research, 2001). Most cowpeas are grown on the African continent, particularly in Nigeria and Niger, which account for $66 \%$ of world production (Singh et al, 1997). Brazil is the world's second-leading producer of cowpea seed, accounting for $17 \%$ of annual cowpea production (Gómez, 2004). Large quantity of pods is generated from production of cowpea. Utilization of WCHA as an additive or partial replacement to cement in concrete production will enhance more cultivation of cowpea. However, limited or no information is available on its previous utilization in concrete

\section{Materials and methods}

The materials used for the research include the following:

\subsection{White Cowpea Husk Ash}

WCHA was collected from a farmland in Gezawa Local Government Area where there is mass production of cowpea. Burning of white cowpea (beans) husk was carried out under controlled temperature of between $500-700{ }^{\circ} \mathrm{C}$ using the incinerator available in School of Technology, Kano State Polytechnic, Kano State, Nigeria. The ash was ground and sieved to produce a finer ash.

\subsubsection{Cement}

The Cement used for the investigation is manufactured by Dangote cement company (CEM II/AL, $42.5 \mathrm{~N})$.

\subsubsection{Aggregate}

Clean river sand (fine aggregate) and crushed rock (coarse aggregate) were used throughout the research. The coarse aggregate size was $20 \mathrm{~mm}$ and both conformed to BS 882:1992. The WCHA before and after calcination are shown in plate $1 \mathrm{a}$ and $1 \mathrm{~b}$ respectively.

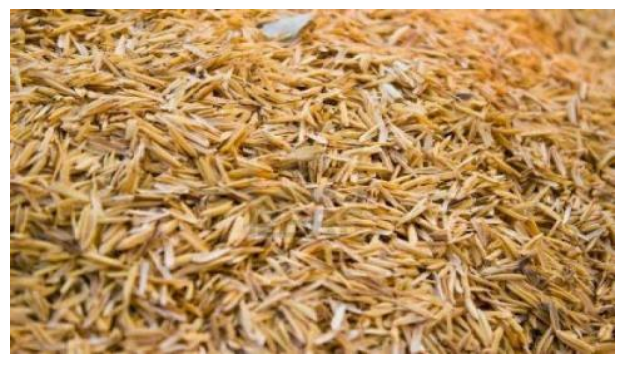

Plate 1a: Cowpea Pod before Calcination

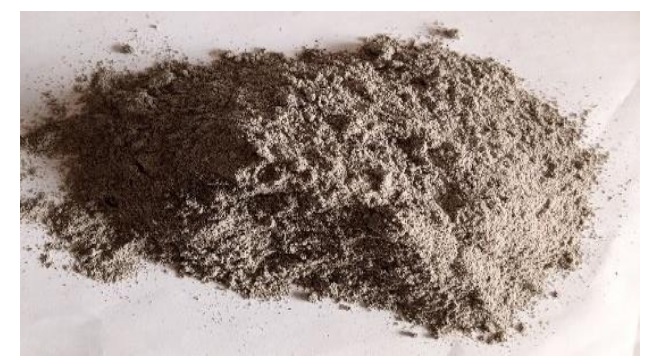

Plate 1b: Calcined Cowpea Pod Ash

The fresh concrete was produced manually following the laid down procedure given in BS 1881125 (2013). Cement, sand and crushed rock was proportioned by weight as shown in Table 1 and mixed homogeneously using water cement ratio obtained from the mix design. Fresh concrete with $0,5,10,15,20$ and $25 \%$ WCHA replacement of cement by weight respectively were produced following same procedure and treatment. The fresh property of the concrete using slump test was checked and the concrete thereafter was cast in clean and oiled moulds for compressive strength, splitting tensile and flexural strengths. After allowing the concrete to harden for 24 hours, the cubes were demoulded and dipped in a curing tank filled with water until the testing period was reached. Plate $2 \mathrm{a}$ and $2 \mathrm{~b}$ shows the batching procedure for the concrete. 
Table 1. Material proportioning for concrete

\begin{tabular}{|c|c|c|c|c|c|}
\hline$\%$ WCPA & $\begin{array}{c}\text { WCHA } \\
\left(\mathrm{kg} / \mathrm{m}^{3}\right)\end{array}$ & $\begin{array}{c}\text { Cement } \\
\left(\mathrm{kg} / \mathrm{m}^{3}\right)\end{array}$ & $\begin{array}{c}\text { Sand } \\
\left(\mathrm{kg} / \mathrm{m}^{3}\right)\end{array}$ & $\begin{array}{c}\text { Granite } \\
\left(\mathrm{kg} / \mathrm{m}^{3}\right)\end{array}$ & $\begin{array}{c}\text { Water } \\
\left(\mathrm{kg} / \mathrm{m}^{3}\right)\end{array}$ \\
\hline \hline 0 & 0 & 380 & 625 & 1165 & 190 \\
\hline 5 & 19 & 361 & 625 & 1165 & 190 \\
\hline 10 & 38 & 342 & 625 & 1165 & 190 \\
\hline 15 & 57 & 323 & 625 & 1165 & 190 \\
\hline 20 & 76 & 304 & 625 & 1165 & 190 \\
\hline 25 & 95 & 285 & 625 & 1165 & 190 \\
\hline
\end{tabular}
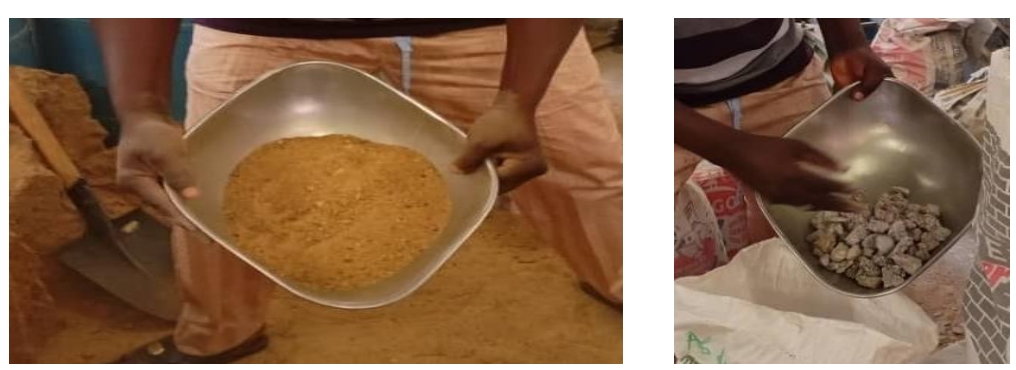

Plate 2a and 2b: Batching of Material

\section{Results and discussion}

\subsection{Tests on WCHA, Cement and Aggregate}

The following tests were carried out on various material samples; XRF analysis, specific gravity, consistency, setting time and particle size distribution. The tests were carried out in accordance with the provision by various standard codes discussed in the Materials and Methods section. The results obtained are presented in Tables $2-3$ and Figures $1-6$.

Table 2. Oxide Composition using XRF analysis

\begin{tabular}{|c|c|c|}
\hline Oxides & WCHA (\%) & CEMENT (\%) \\
\hline \hline $\mathrm{SiO}_{2}$ & 41.641 & 20.171 \\
\hline $\mathrm{Al}_{2} \mathrm{O}_{3}$ & 13.682 & 4.101 \\
\hline $\mathrm{Fe}_{2} \mathrm{O}_{3}$ & 10.066 & 3.899 \\
\hline $\mathrm{CaO}$ & 20.542 & 63.871 \\
\hline $\mathrm{MgO}$ & 2.001 & 2.105 \\
\hline $\mathrm{SO}_{3}$ & 1.401 & 2.1 \\
\hline $\mathrm{Na}_{2} \mathrm{O}$ & 0.234 & 0.011 \\
\hline $\mathrm{K}_{2} \mathrm{O}$ & 1.135 & 0.938 \\
\hline $\mathrm{P}_{2} \mathrm{O}_{5}$ & 1.879 & 0.117 \\
\hline $\mathrm{Cl}$ & 0.086 & 0.098 \\
\hline $\mathrm{TiO}_{2}$ & 0.287 & 0.209 \\
\hline $\mathrm{Cr}_{2} \mathrm{O}_{3}$ & 0.001 & 0.003 \\
\hline $\mathrm{Mn}_{2} \mathrm{O}_{3}$ & 0.02 & 0.036 \\
\hline $\mathrm{ZnO}$ & 0.237 & 0.011 \\
\hline $\mathrm{SrO}$ & 0.011 & 0.232 \\
\hline $\mathrm{LoI}$ & 6.773 & 2.093 \\
\hline
\end{tabular}

The oxide composition presented in Table 2 shows that the cement has $\mathrm{CaO}+\mathrm{SiO}_{2}: 84.042(\geq 50$ \%), $\mathrm{CaO} / \mathrm{SiO}_{2}: 3.166$ ( $\geq 2 \%$ ), $\mathrm{SO}_{3}: 2.1$ ( $\leq 3.5 \%$ ), $\mathrm{MgO}: 2.105$ ( $\leq 5.0 \%$ ), Cl: 0.098 ( $\left.\leq .1 \%\right)$. This indicates that the cement satisfied the recommended limit for CEM II $42.5 \mathrm{~N}$ class given in ASTM C618 (2005). In addition, the sum $\mathrm{SiO}_{2}+\mathrm{Al}_{2} \mathrm{O}_{3}+\mathrm{Fe}_{2} \mathrm{O}_{3}$ for WCPA is $65.389 \%$ this is less than the limit ( $\geq 70 \%$ ) provided by ASTM C618 (2005). However, the material could be regarded as class 
C pozzolana since the requirements $\mathrm{SiO}_{2}: 41.641$ ( $\geq 39.90$ ), $\mathrm{SiO}_{2}+\mathrm{Al}_{2} \mathrm{O}_{3}+\mathrm{Fe}_{2} \mathrm{O}_{3}: 65.389$ ( $\geq 50 \%$ ), $\mathrm{SO}_{3}: 1.401(\leq 5.0 \%), \mathrm{Na}_{2} \mathrm{O}: 0.234(\leq 1.5)$ was satisfied.

Table 3. Specific Gravities of Concrete Materials

\begin{tabular}{|c|c|}
\hline Materials & Values \\
\hline Cement & 3.15 \\
\hline WCHA & 2.15 \\
\hline Fine Aggregate & 2.69 \\
\hline Coarse Aggregate & 2.61 \\
\hline
\end{tabular}

From the specific gravities of concrete materials shown in Table 3, it was deduced that the specific gravity of the cement is within the recommended value of $3.10-3.16$ for ordinary Portland cement (OPC) (ASTM C 188, 2005). WCHA has a specific gravity of 2.15. This shows that WCHA is less dense than OPC and hence signifying lesser volume of cement required more volume of equal mass of WCHA. The specific gravities of fine and coarse aggregates fall within the specified limit as specified by ACI Education Bulletin, 2007.

\subsection{Particle size distribution}

The particle size distribution of the aggregates carried out by dry sieving is presented in Figure 1.

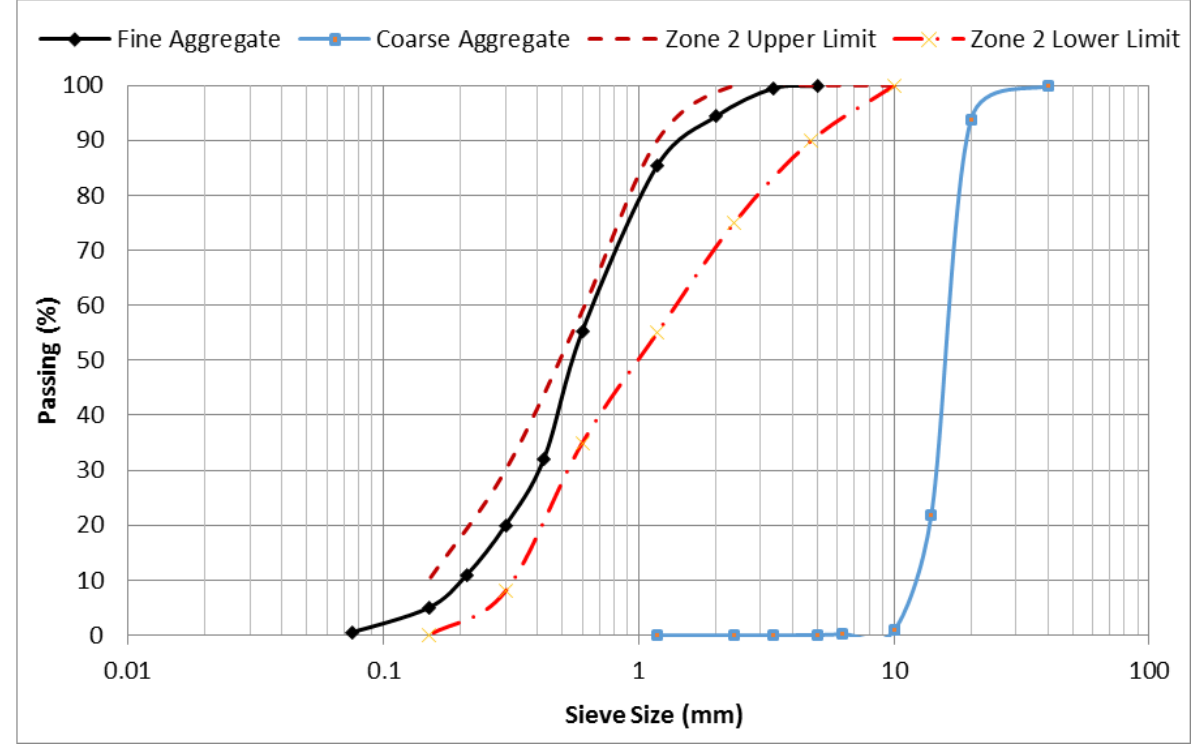

Fig. 1. Particle Size Distribution of Fine and Coarse Aggregates

The result of the particle size distribution of fine aggregate as presented in Figure 1 shows that the fine aggregate has fineness modulus of 2.57 and it belongs to zone II class based on BS EN 12620:2002+A1:2008 grading limits for fine aggregates. The result of the particle size distribution of the coarse aggregates as presented in the figure shows that the coarse aggregate has dominant particle size of $20 \mathrm{~mm}$ with only 71.82 and $21.96 \%$ retained and passing $14 \mathrm{~mm}$ sieve respectively. Hence, the coarse aggregate could be regarded $20 \mathrm{~mm}$ size. In addition, the fineness modulus of the coarse aggregate is 6.97.

\subsection{Effect of WCHA on Consistency of Cement Paste}

The consistency of cement paste with varied proportion of WCHA is presented in Figure 2. The consistencies ranged from $30 \%$ at $0 \%$ WCPA to $39 \%$ at $25 \%$ WCPA. This suggests that the consistency of the cement paste increases with increase in WCHA content. The increase in consistencies with increase in WCHA content could be due to high LoI of WCHA compared to 
that of the cement. This finding is similar to the observations of Ogork et al (2014) and Jaturapitakkul and Roongreung (2003). This result is also linked to the lower specific gravity of WCHA when compared to that of cement (Ogork et al, 2014).

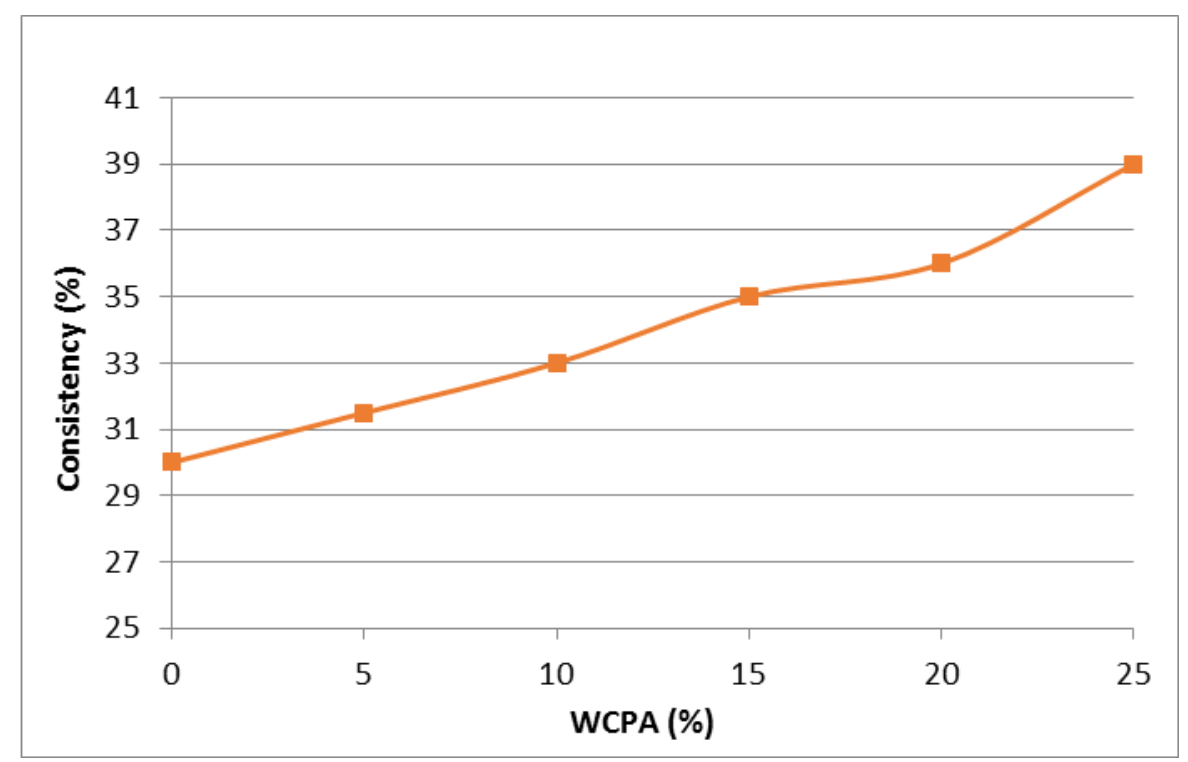

Fig. 2. Consistency of binder with varied proportion of WCPA

\subsection{Effect of WCHA on Initial Setting and Final Setting Time of Cement Paste}

The initial setting and final setting time of WCHA-Cement paste ranged from 76 to 168 minutes and 172 to 351 minutes respectively for 0 to $25 \%$ WCHA replacement as shown in Figure 3. The initial and final setting time of WCHA-cement is within the allowance specified in BS EN 197-1 (2011) ( $\geq 60$ minutes) and ( $\leq 10$ hours) respectively for $42.5 \mathrm{~N}$ graded OPC. In addition, the results indicate that the initial and final setting times of WCPA - Cement paste increase with increase in WCPA content. The delay in setting times of higher percentage content of WCHACement paste could be as a result of the slower pozzolanic reaction (Jaturapitakkul and Roongreung, 2003 and Ogork et al, 2014) of WCHA. In addition, the delay of setting times of WCHA - cement could also be due to lower cement content and dispersion effect provided by the WCHA on the cement particles (Gesoglu and Erdogan, 2007 and Ezziane et al., 2010).

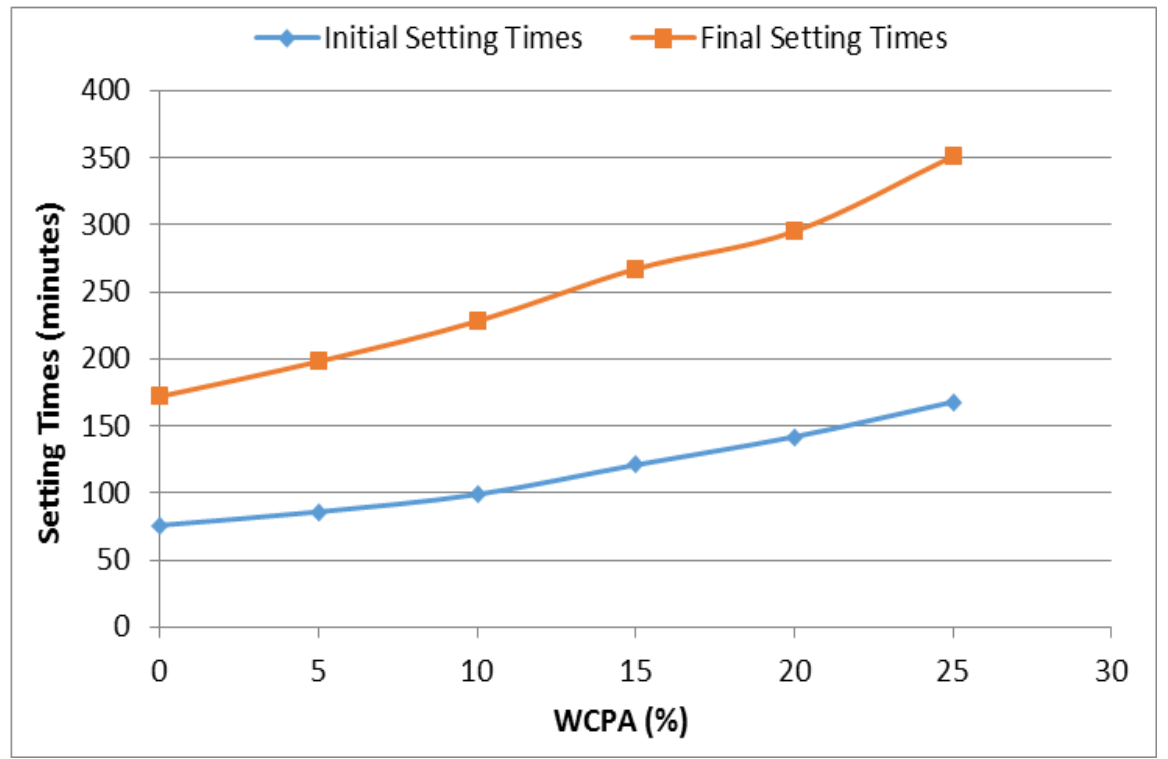

Fig. 3. Setting time with varied proportions of WCPA 


\subsection{Effect of WCHA on the Properties of Fresh Concrete}

The workability of the fresh concrete using slump test method carried out in accordance with BS 1881-102(2000) was used to assess the effect of WCHA on the properties of fresh concrete. The result as presented in Figure 4 shows that the workability of the fresh concrete reduces with increase in WCHA content. The reduction in workability could be as a result of the decrease in fluidity of the mix due to high water demand of WCHA (Obilade, 2014). In addition, the reduction could also be attributed to reduction in density of the mix as WCHA content increases (Said et al., 2014 and Ogork and Auwal, 2016) as well as its fineness modulus as compared to that of cement.

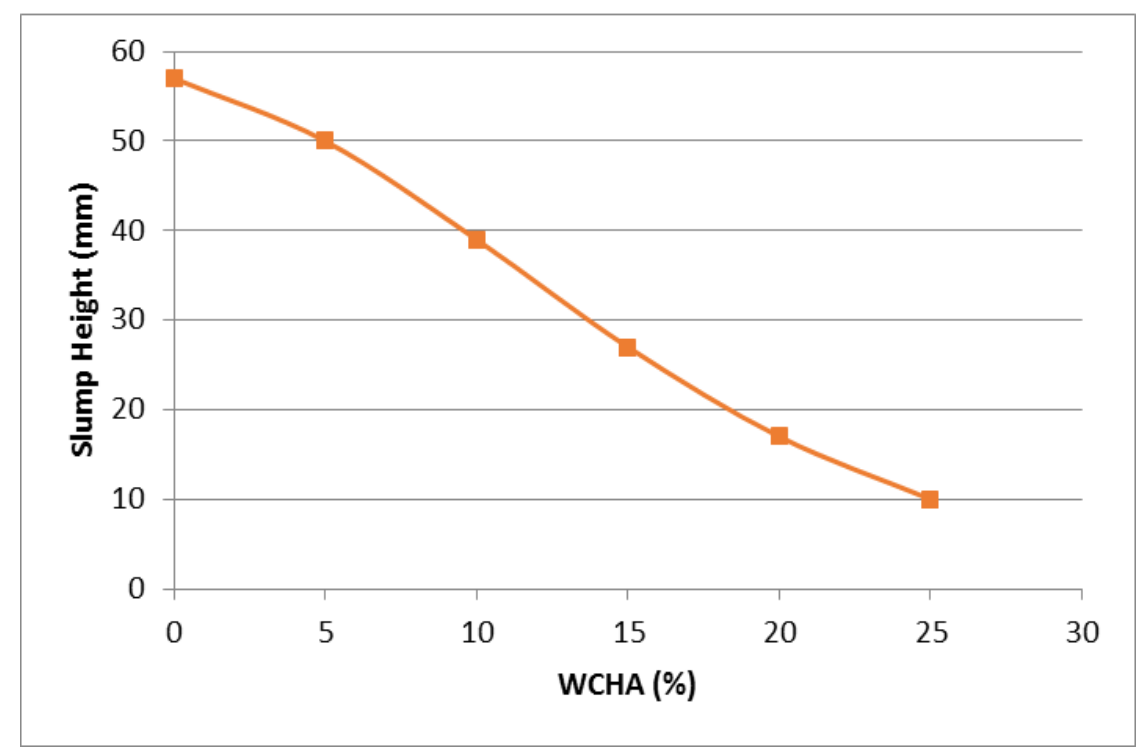

Fig. 4. Workability of WCHA - Concrete

\subsection{Effect of WCHA on the Density of Concrete}

The effect of WCHA on the density of concrete is shown in Figure 5. The density of the concrete decreased as the WCHA content increases possibly owing to the lower specific gravity of WCHA than that concrete. The peak density is at $5 \%$ replacement of WCHA. The density range between $2515 \mathrm{~kg} / \mathrm{m}^{3}-2286 \mathrm{~kg} / \mathrm{m}^{3}$.

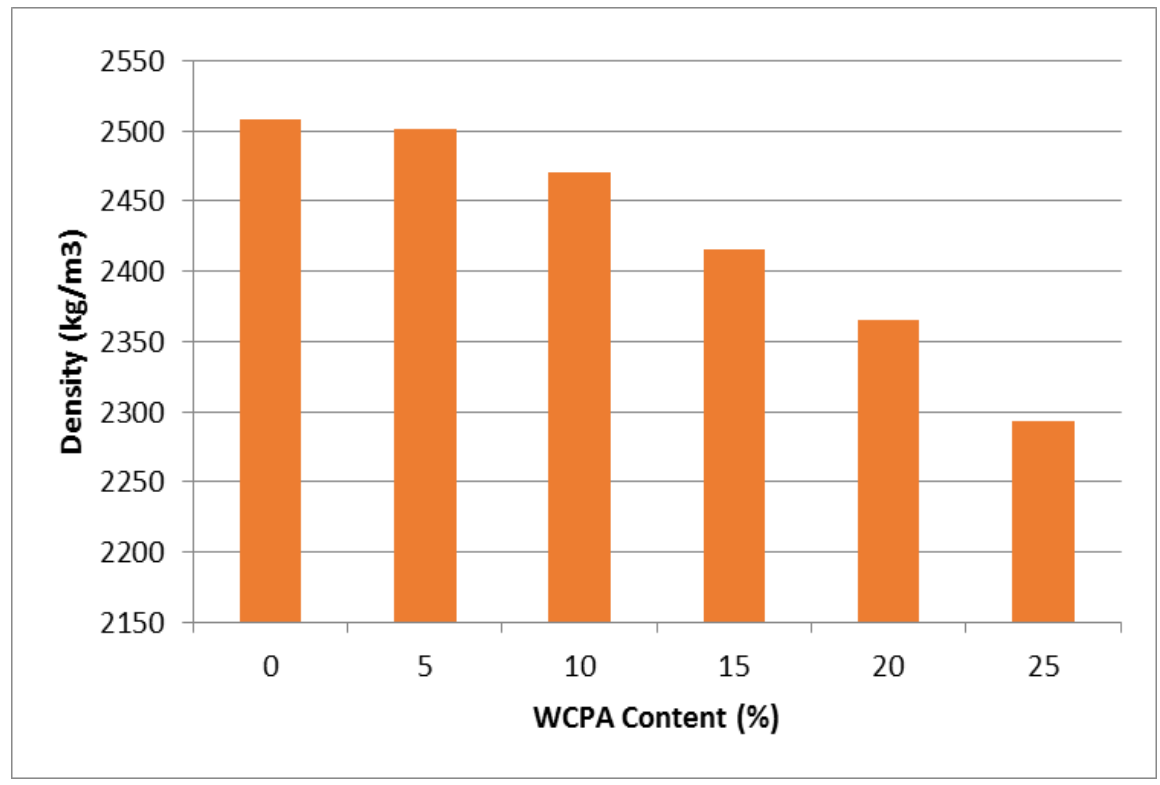

Fig. 5. Effect of WCHA on Density of Concrete 


\subsection{Effect of WCHA on the Compressive Strength of Concrete}

Generally the compressive strength of the WCHA concrete increased with increase in curing age and decreases as the WCHA content increased. The strength declined from 28.6 to $20.0 \mathrm{~N} / \mathrm{mm}^{2}$ giving a percentage reduction of $30.1 \%$ as shown in Figure 6 . The reduction in strength could be attributed to decrease in densities of the concrete as WCHA content increases. The strength reduction could also be as a result of modification of the bonding properties of the binders' hydrates as reported by Phan et al, 2001 and Kanema, 2007). However, the 28 days compressive strength of concrete with up to $10 \%$ WCHA content $\left(26.4 \mathrm{~N} / \mathrm{mm}^{2}\right)$ satisfies the design characteristic strength of $25 \mathrm{~N} / \mathrm{mm}^{2}$. Beyond this limit, the compressive strength of the concrete was below the design strength. Hence, $10 \%$ WCPA could be regarded as the optimum dose for grade 25 concrete.

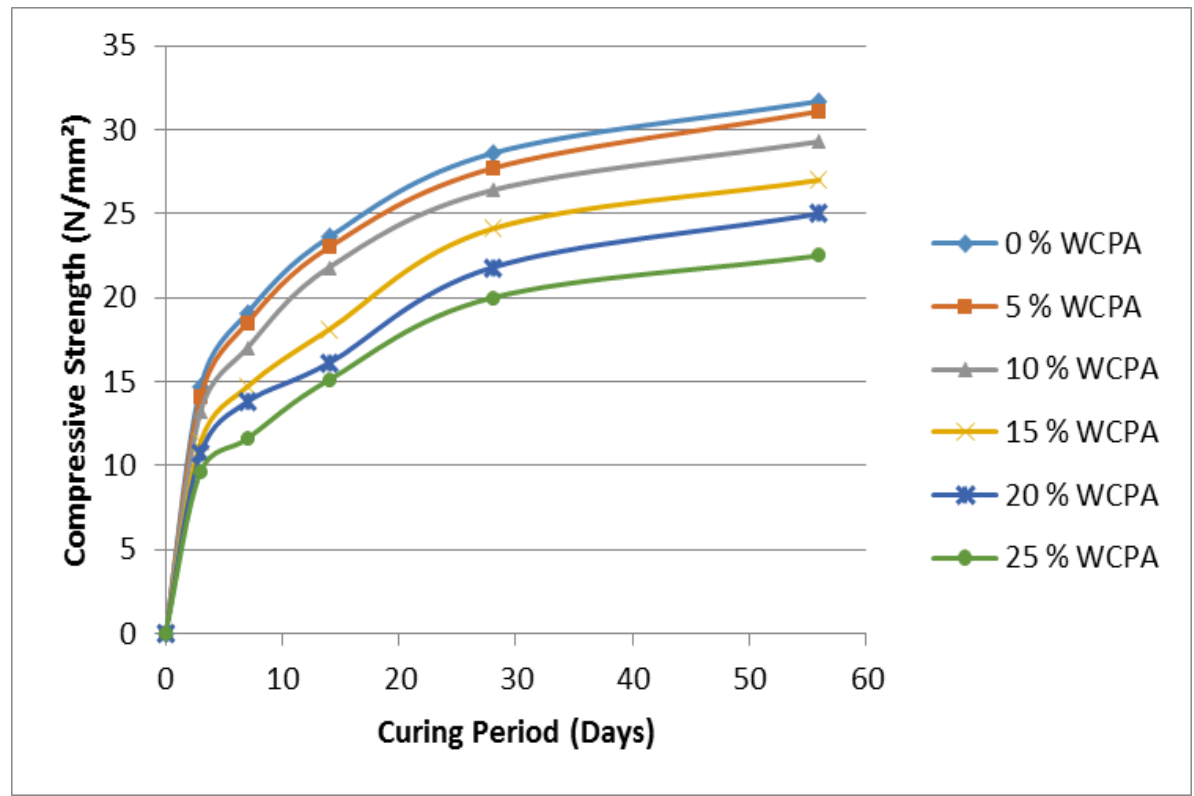

Fig. 6. Compressive Strength of WCHA - Concrete

\section{Conclusions}

From the oxide composition of WCHA, it can be concluded that WCHA satisfies the requirement for class $\mathrm{C}$ pozzolana as provided by ASTM C618. The consistency, initial and final setting time of cement increased with increase in WCHA content. WCHA reduces the workability of a concrete. Grade 25 concrete can be satisfactorily produced using up to $10 \%$ WCHA replacement of cement by weight.

\section{Disclosure statement}

No potential conflict of interests of any form regarding the publication of this manuscript is available.

\section{Acknowledgement}

All contributors were acknowledged including a late colleague that assisted in the research.

Funding and Sponsors: This research was self-funded.

With pain, we wish to acknowledge the tremendous scholarship of Late Dr. J. O. Afolayan who initiated this research concept and therefore dedicate the entire work to his loving memory. 


\section{References}

Aboshio, A., Shuaibu, H. G. and Abdulwahab, M. T. (2018). Properties of Rice Husk Ash Concrete with Periwinkle Shell as Coarse Aggregates. Nigerian Journal of Technological Development, Vol. 15, No. 2, pp. 33-38.

ACI Education Bulletin (2007). Aggregate for concrete- Materials for Concrete Construction. Developed by Committee E-701, American Concrete Institute, 38800 Country Club Dr. Farmington Hills, Michigan, United State.

ASTM C618 (2005). Standard Specification for coal fly ash and raw or calcined natural pozzolan for use in concrete. America Standard of Testing Materials International, West Conshohocken.

Atan M. N. and Awang H. (2011). The Compressive and Flexural Strengths of Self Compacting Concrete using Raw Rice Husk Ash. Journal of Engineering, Science and Technology, Vol. 6, No. 6, pp. 720-732

Awang H., Atan M. N., Zainul Abidin N. and Yusof N. (2016). A Cost-Reduction of Self - Compacting Concrete Incorporating Raw Rice Husk Ash. Journal of Engineering Science and Technology. Vol. 11, No. 1, pp. 096-108

BS 1881 - 102 (2000),' Method for Determination of Slump' British Standard BSI Group Headquarters 389 Ciswick High Road, London, W4 4Al, UK, Standards Policy and Strategy Committee.

BS 1881-125 (2013) Testing Concrete. Method for Mixing and Sampling of fresh concrete in the Laboratory. British Standard BSI Group Headquarters 389 Ciswick High Road, London, W4 4Al, UK, Standards Policy and Strategy Committee.

BS 882. (1992). Specification for Aggregates from Natural Sources for Concrete. British Standard BSI Group Headquarters 389 Ciswick High Road, London, W4 4Al, UK, Standards Policy and Strategy Committee.

BS 882. (1992). Specification for Aggregates from Natural Sources for Concrete. British Standard BSI Group Headquarters 389 Ciswick High Road, London, W4 4Al, UK, Standards Policy and Strategy Committee.

BS EN 12620:2002+A1:2008. (2008). Specification for Aggregate from natural sources for concrete. British Standard BSI Group Headquarters 389 Ciswick High Road, London, W4 4Al, UK, Standards Policy and Strategy Committee.

BS EN197-1 :(2011). “Composition, specification and conformity criteria for common cements". British Standard BSI Group Headquarters 389 Ciswick High Road, London, W4 4Al, UK, Standards Policy and Strategy Committee.

Esping, O. (2008). Effect of Limestone Filler BET(H20)-area on the Fresh and Hardened Properties of Self Compacting Concrete. Cement and Concrete Research, 38, 938-944.

European Concrete (2009). Sustainable Benefits of Concrete Structures. European Concrete Platform ASBL, Brussels, Belgium.

Ezziane, K., Kadri, E.H., Hallal, A. and Duval, R. (2010). Effect of mineral additives on the setting of blended cement by maturity method. Materials and Structures, 43, 393-401.

Felekoglu, B. (2007). Utilisation of High Volumes of Limestone Quarry Wastes in Concrete Industry (SelfCompacting Concrete Case). Resources, Conservation and Recycling, 51, 770-791.

Gesoglu, M. and Erdogan, O.E. (2007). Effect of mineral admixtures on fresh and hardened properties of self-compacting concretes, Binary, ternary and quaternary systems, Material Structures, 40, 923-937. 
Gesoglu, M., Guneyisi, E. and Ozbay, E. (2009). Properties of Self Compacting Concretes made with Binary, Ternary, and Quaternary Cementitious Blends of Fly Ash, Blast Furnace Slag, And Silica Fume. Construction and Building Materials, 23(5), 1847-1854.

Gómez, C. (2004). "Cowpea Post-harvest Operations". Food and Agriculture Organization of the United Nations. Retrieved 2017-04-19.

Habeeb, G.A. and Fayyadh, M.M. (2009). Rice husk ash concrete: the effect of RHA average particle size on mechanical properties and drying shrinkage. Australian Journal of Basic and Applied Sciences. 3(3): p. 1616-1622.

IITA (2008). The International Institute of Tropical Agriculture (2008). Retrieved from http://intranet/iita4/crop/maize.htm

Jaturapitakkul, C. and Roongreung, B. (2003). Cementing Material from Calcium Carbide Residue Rice Husk Ash, Journal of Materials in Civil Engineering, 15(5), 470-475.

Kanema M. (2007). Doc. Thes (French), Univ. Cergy-Pontoise.

Liu, M. (2010). Self-Compacting Concrete with different levels of Pulverized Fuel Ash. Construction and Building Materials, 24(7), 1245-1252.

Malhotra, V.M. and Mehta, P.K. (2002). High-Performance, High-Volume Fly Ash Concrete, Supplementary Cementing Materials for Sustainable Development, Inc., Ottawa, Canada.

Marland, G., Boden, T.A., Griffin, R.C., Huang, S.F., Kanciruk, P. and Nelson, T.R. (1989). Estimates of CO2 Emissions from Fossil Fuel Burning and Cement Manufacturing, Based on the United Nationals Energy Statistics and the U.S. Bureau of Mines Cement Manufacturing Data. Report No. \#ORNL/CDIAC-25, Carbon Dioxide Information Analysis Centre, Oak Ridge National Laboratory, Oak Ridge, Tennessee, USA.

Odeyemi, S. O., Atoyebi, O. D. and Ayo, E. K. (2020). Effect of Guinea Corn Husk Ash on the Mechanical Properties of Lateritic Concrete. IOP Conf. Series: Earth and Environment Science, 445, 012034, pp. 111.

Ogork, E. N. and Uche, O. A. (2014). Effects of Groundnut Husk Ash (GHA) in Cement Paste and Mortar. International Journal of Civil Engineering and Technology (IJCIET), Volume 5, Issue 10, pp. 88-95.

Ogork, E.N. and Auwal, A.M. (2016): Mechanical properties of self-compacting concrete (SCC) made with corn-cob ash (CCA). Book of Proceedings of the 15th Annual International Conference/ Nigerian Materials Congress (NIMACON 2016), 21st - 25th November, 2016, Ahmadu Bello University, Zaria Kaduna State, Nigeria, pp. 379-383.

Phan L.T., Lawson J.R. and Davis F.L. (2001). Material Structure 34, 83-91.

Siddique, R. (2011). Properties of self-compacting concrete containing class F fly ash. Materials and Design, 32, 1502-1507.

Singh, B. B., Chambliss, O. L. and Sharma, B. (1997). "Recent advances in cowpea breeding" (PDF). In Singh, B. B.; Mohan, D. R.; Dashiell, K. E.; Jackai, L. E. N. (eds.). Advances in Cowpea Research. Ibadan, Nigeria: International Institute of Tropical Agriculture and Japan International Research Center for Agricultural Sciences.

Sukumar, B., Nagamani, K. and Raghavan, R. S. (2008). "Evaluation of strength at early ages of selfcompacting concrete with high volume fly ash," Construction and Building Materials, vol. 22, no. 7, pp. 1394-1401.

Turkel, S. and Altuntas, Y. (2009). The effect of limestone powder, fly ash and silica fume on the properties of self-compacting repair mortars. Sadhana (India), 34(2), 331-343. 
Yazici, H. (2008). The effect of silica fume and high-volume Class C fly ash on mechanical properties, chloride penetration and freeze-thaw resistance of self-compacting concrete. Construction and Building Materials, 22(4), 456-462.

Ye, G., Liu, X., De Schutter, G., Poppe, A.M., and Taerwe, L. (2007). Influence of Limestone Powder used as filler in SCC on Hydration and Microstructure of Cement Pastes. Cement and Concrete Composites, 29, 94-102. 